\title{
The skeleton: a multi-functional complex organ. The role of key signalling pathways in osteoclast differentiation and in bone resorption
}

\author{
David J Mellis, Cecile Itzstein, Miep H Helfrich and Julie C Crockett \\ Musculoskeletal Research Programme, University of Aberdeen, Institute of Medical Sciences, Foresterhill, Aberdeen AB252ZD, UK \\ (Correspondence should be addressed to J C Crockett; Email: j.c.crockett@abdn.ac.uk)
}

\begin{abstract}
Osteoclasts are the specialised cells that resorb bone matrix and are important both for the growth and shaping of bones throughout development as well as during the process of bone remodelling that occurs throughout life to maintain a healthy skeleton. Osteoclast formation, function and survival are tightly regulated by a network of signalling pathways, many of which have been identified through the study of rare monogenic
\end{abstract}

diseases, knockout mouse models and animal strains carrying naturally occurring mutations in key molecules. In this review, we describe the processes of osteoclast formation, activation and function and discuss the major transcription factors and signalling pathways (including those that control the cytoskeletal rearrangements) that are important at each stage.

Journal of Endocrinology (2011) 211, 131-143

\section{Introduction}

Osteoclasts are required during skeletal development to form and shape bones and throughout life in the process of remodelling that maintains the bone tissue in a healthy state by the continual repair of microfractures (reviewed in Crockett et al. (2011b)). Osteoclasts are generally large multinucleated cells, but small, even mononuclear, osteoclasts also exist and can be fully functional. Osteoclast formation and survival and their unique ability to resorb bone are controlled by signalling pathways leading to the activation of transcription factors, with the NFKB pathway being of particular importance. The control of osteoclast differentiation and function by signalling pathways is highlighted by conditions in which key components of such pathways are mutated or absent leading to diseases associated with dramatic changes in osteoclast number or activity (Crockett et al. 2011a). In addition, new genetic information links specific signalling pathways to increased risk of developing complex bone diseases such as osteoporosis. In this review, we describe the process of osteoclast formation and resorption, focusing specifically on some of the key signalling pathways involved. This review is not exhaustive; we have not touched on the

\footnotetext{
This paper is one of three papers that form part of a thematic review section on the skeleton: a multi-functional complex organ. The Guest Editor for this section was Colin Farquharson, Roslin Institute, University of Edinburgh, UK.
}

important role of osteoclasts in regulating osteoblasts and the signalling pathways involved in this process; we also have not reviewed all the signalling pathways regulating osteoclast function that are shared with the immune system. We encourage the reader to consult other recent reviews in these areas (Edwards \& Mundy 2008, Sims \& Gooi 2008, Takayanagi 2009).

\section{Osteoclastogenesis}

Osteoclasts are formed from myeloid cells of the haematopoietic lineage. In early embryonic life these precursors form in the blood islets in the extra-embryonic tissue. When the embryo becomes vascularised they travel into the embryo proper and establish sites of blood cell formation initially in the foetal liver and spleen and eventually, when endochondral bone formation is complete, they move into the bone marrow space with some blood cell formation also becoming established in sites of intramembranous ossification. Osteoclasts have been successfully cultured from all of these tissues in vitro at various stages of embryonic and foetal development in the mouse (Thesingh 1986), as well as from precursors present in the adult mouse circulation (Helfrich et al. 1989), and more recently from precursors in the human circulation, which is now common practice in osteoclast research. While we consider osteoclasts derived from all precursors as identical for the purposes of this review, there is increasing information suggesting that perhaps different osteoclast precursors exist in different anatomical sites 
(Everts et al. 2009) and this may be related to events very early on in osteoclast ontogeny. Osteoclast development is studied most often in precursor cells derived from bone marrow (mouse) or the circulation (human), while information about mature osteoclasts is often obtained in vitro from cells isolated from neonatal rabbits, from in vivo model systems and from the study of human bone disease. We review the consensus that has emerged from these studies below.

\section{Osteoclast precursor commitment}

Human diseases and genetically engineered or spontaneous mutant rodent lines have demonstrated that deletion of or mutations within any of the genes that encode factors required for commitment to this lineage or for the activation of mature osteoclasts result in the high bone mass condition osteopetrosis (Villa et al. 2009). Commitment of cells to the myeloid lineage (see Fig. 1A) is determined through the expression of transcription factor PU.1, a member of the ETS family of transcription factors (Scott et al. 1994). Deletion of PU.1 in mice results in a complete lack of differentiation of cells to the monocyte/macrophage lineage and causes osteopetrosis as a result of lack of osteoclast formation (Tondravi et al. 1997). Many genes required for osteoclast formation and function have PU.1 binding sites within their promoters (Luchin et al. 2000, 2001, Matsumoto et al. 2004, Kim et al. 2005). Importantly, in the early stages of haematopoietic stem cell commitment to the monocyte/ macrophage lineage, PU.1 stimulates the expression of CSF1R, the receptor for CSF1, commonly referred to as macrophage colony-stimulating factor (M-CSF; DeKoter et al. 1998). M-CSF and CSF1R are well established as critical components required for the generation of osteoclasts. Animal models in which CSF1R is knocked down develop severe osteopetrosis as a consequence of reduced osteoclast numbers. A similar osteopetrotic phenotype is observed within naturally occurring mutations in M-CSF as in the op/op mouse or the $t l / t l$ rat, highlighting the critical role of this pathway in commitment to the monocyte lineage (Felix et al. 1990b, Yoshida et al. 1990, Wojtowicz et al. 1997, Dai et al. 2002).

The osteoclast differentiation defect in op/op mouse can be fully rescued by injecting M-CSF (Felix et al. 1990a), and the monocyte defect can be overcome by expressing the prosurvival factor BCL-2 (Lagasse \& Weissman 1997). Signalling through CSF1R induces expression of receptor activator of NFKB (RANK; TNFRSF11A) via up-regulation of the transcription factor c-FOS. In addition, RANK expression is controlled by PU.1 in cooperation with other transcription factors (Kwon et al. 2005). Elegant animal studies have revealed the critical role for activator protein 1 (AP-1) in osteoclastogenesis. The AP-1 heterodimeric transcription factor complexes comprise members of the Fra, Fos, Jun and activating transcription factor (ATF) families. Deletion of the $c$-Fos gene results in osteopetrosis by halting osteoclast differentiation at the macrophage stage and this defect can be completely rescued by expressing FOS protein (Grigoriadis et al. 1994). Despite the
A

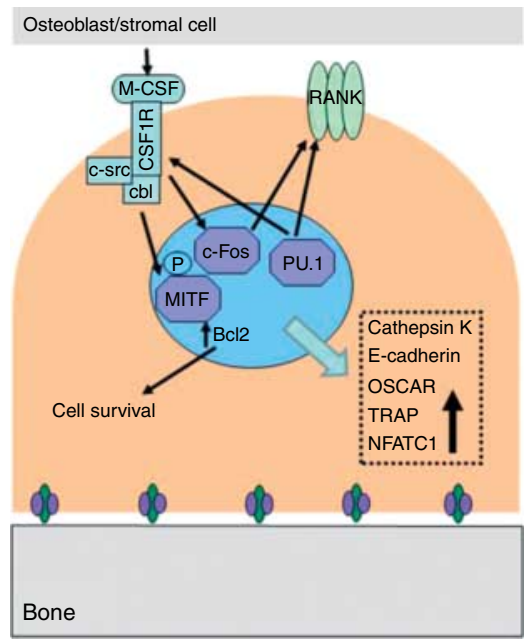

B

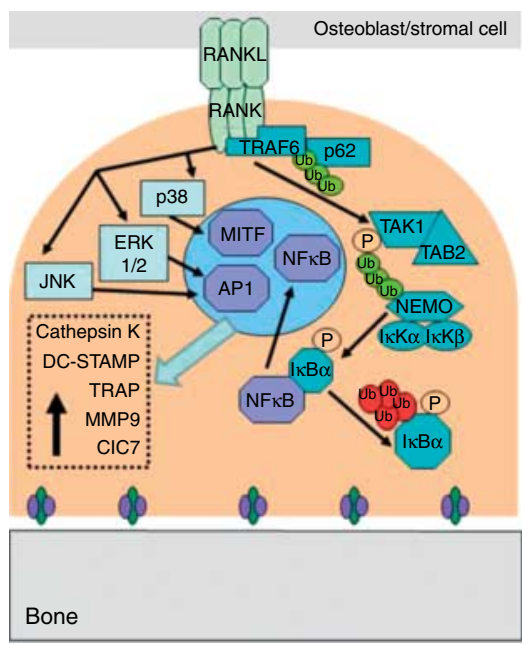

Figure 1 The transcription factor PU.1 is responsible for committing haematopoietic stem cells to the monocyte/macrophage lineage (osteoclast precursors). (A) PU.1 stimulates the expression of the CSF1 R receptor in the osteoclast precursors. Macrophage colonystimulating factor (M-CSF) signalling is activated by M-CSF to promote macrophage proliferation. Microphthalmia-induced transcription factor (MITF) is up-regulated by M-CSF and through the induction of BCL-2 stimulates macrophage survival. M-CSF and PU.1 also up-regulate expression of receptor activator of NFKB (RANK). (B) Activation of the RANK receptor through binding of RANK ligand (RANKL) results in the recruitment of TRAF6 to the cytoplasmic domain of RANK. A K63-polyubiquitin chain (green) forms on TRAF6, which is stabilised by the scaffold protein p62, to create a platform for the assembly of the TAB2/TAK1 complex. Phosphorylation of TAK 1 results in the K63-polyubiquitination of NEMO and the subsequent phosphorylation of IKK $\alpha$ that phosphorylates the inhibitory protein I $\mathrm{KB} \alpha$, targeting it for K48ubiquitination (red) and degradation. In addition, RANKL activates MAP kinase pathways resulting in the phosphorylation of ERK1/2 and c-jun N-terminal kinase (JNK) that activate AP-1 transcription factors and p38 that activates MITF. Following activation, the NFKB, AP-1 and MITF transcription factors enter the nucleus to regulate the expression of genes required for osteoclast differentiation. 
critical role for c-FOS in osteoclastogenesis, its precise binding partners in vivo have yet to be determined but it is most likely to interact with Jun family members. FRA-1 also plays a role in osteoclast differentiation (Wagner \& Eferl 2005) where FRA-1 can substitute for c-FOS deficiency but not when partnered with Jun proteins and indeed, as with c-FOS, the exact binding partner for FRA-1 remains to be identified (Bakiri et al. 2007).

Microphthalmia-induced transcription factor (MITF) is another key transcription factor important in the late stages of osteoclastogenesis that becomes activated in response to the initiation of signalling via the CSF1R and RANK receptors. Naturally occurring mutations in Miff ( $m i / m i$ mouse) cause severe osteopetrosis as a result of reduced osteoclast formation and fusion (Murphy 1973, Thesingh \& Scherft 1985) whereas varying degrees of osteopetrosis result from other mutations within the protein (Sharma et al. 2009). Activation of MITF in response to $\mathrm{M}$-CSF induces BCL-2 expression and promotes macrophage survival (McGill et al. 2002). In addition, MITF in conjunction with PU.1 up-regulates the expression of the critical osteoclast receptor RANK via MITF binding sites within the $R A N K$ promoter (Ishii et al. 2008). There are three isoforms of MITF but only one, MITF-E, is up-regulated during osteoclastogenesis (Lu et al. 2010). In macrophage precursors, association of MITF and PU.1 with corepressors, including EOS, an Ikaros family member, prevents the activation of osteoclastspecific genes. During osteoclast differentiation, however, EOS expression decreases allowing MITF and PU.1 to become active and up-regulate osteoclastogenesis (Hu et al. 2007). MITF and PU.1 regulate other transcription factors that control osteoclast formation and activation through binding to various promoter sites. These include the up-regulation of osteoclast critical genes including nuclear factor of activated T-cells cytoplasmic 1 (NFATc1), vacuolar ATPase and cathepsin K (Sharma et al. 2007). Indeed, promoter reporter assays demonstrated that cathepsin $\mathrm{K}$ promoter activation is prevented in the presence of MITF containing osteopetrosis-causing mutations and cathepsin $\mathrm{K}$ expression is lower in cells isolated from $\mathrm{mi} / \mathrm{mi}$ mice (Motyckova et al. 2001).

\section{Formation of mature osteoclasts}

RANK ligand (RANKL; TNFSF11) is expressed by osteoblasts and stromal cells. Activation of RANK signalling by RANKL (via the pathway illustrated in Fig. 1B) leads to expression of genes required for the fusion of mononuclear osteoclast precursors, such as dendritic cell specific transmembrane protein (DC-STAMP), as well as of genes required for regulating the resorptive capacity of multinucleated osteoclasts, including those encoding vacuolar ATPase, CLC-7, cathepsin K, MMP9 and calcitonin receptor (Crockett et al. 2011b). During this maturation process, the cells become quiescent, lose the ability to proliferate and are committed to become osteoclasts (Fig. 1B). Recent evidence has emerged for the presence of circulating quiescent osteoclast precursors that already express RANK, suggesting that the early stages of commitment to the lineage take place at sites distant from bone, for example in the spleen, and that such committed cells can immediately differentiate into osteoclasts upon exposure to RANKL when they enter the bone marrow (Takahashi et al. 2010). It has been suggested that entry of the committed osteoclast precursors into the bone remodelling sites is controlled by quiescent osteoblasts (perhaps bone lining cells) that form a canopy over the bone remodelling compartment. Such canopies are disrupted in diseases associated with dysfunctional bone turnover such as osteoporosis and myeloma (Andersen et al. 2010).

Deletion of RANK (Tnfrsf11A) or RANKL (Tnfsf11) in mice and presence of loss-of-function mutations in humans have been associated with osteoclast-poor osteopetrosis caused by lack of osteoclast formation in both mice and humans (Dougall et al. 1999, Hsu et al. 1999, Kong et al. 1999, Sobacchi et al. 2007, Guerrini et al. 2008). In addition, deletion of RANK signalling intermediates (Fig. 1B), including TNFR-associated factor 6 (TRAF6) and NFKB induce an osteopetrotic phenotype (Iotsova et al. 1997, Lomaga et al. 1999). RANK is a type I transmembrane receptor belonging to the TNF receptor superfamily. The crystal structure of the extracellular domain of RANK has recently been described in the presence and absence of RANKL (Ta et al. 2010). These studies showed tight binding between RANK and RANKL and illustrate how single base changes to the receptor-binding domain in RANKL drastically reduce interaction with RANKL and prevent osteoclast formation. Like other members of the TNF family, RANK is a trimeric protein. Binding of the trimeric ligand RANKL, results in activation of the transcription factor $\mathrm{NF \kappa B}$ (Figs $1 \mathrm{~B}$ and 2). NFKB proteins are hetero- or homodimeric transcription factors, consisting of $\mathrm{p} 65$, p 50, p52 and RELB subunits. The critical importance of this transcription factor for osteoclasts is highlighted by the phenotype of mice that lack the p50 or p52 subunit and are unable to form osteoclasts (Franzoso et al. 1997, Iotsova et al. 1997). RANK itself does not possess any kinase activity and relies on signal transduction via the recruitment of other signalling factors to the C-terminal domain. TRAF6 binds to distinct regions of the cytoplasmic domain of RANK (Fig. 1B). Specific deletion of these regions results in a failure to activate $\mathrm{NF \kappa B}$ and inhibits osteoclastogenesis in vitro (Darnay et al. 1999, Armstrong et al. 2002). Although there are consensus binding sites for other TRAFs in RANK, these sites are not essential for NFKB activation in osteoclasts as deletion of Traf2 and Traf5 in mice does not lead to osteopetrosis (Galibert et al. 1998). The signalling events that follow the recruitment of TRAF6 to RANK are complex: a scaffold of proteins forms with TRAF6 that recruits atypical protein kinase $\mathrm{C}(\mathrm{aPKC})$ and facilitates the ubiquitination of TGF $\beta$ activating kinase (TAK1) and the two adaptor molecules TAB1/2, which in turn activate the inhibitory kappa B kinase (IKK) complex resulting in the phosphorylation of the inhibitory kappa $B$ alpha $(\mathrm{I} \kappa \mathrm{B} \alpha)$ which releases $\mathrm{NF} \kappa \mathrm{B}$ to translocate to the nucleus (Fig. 2) and activate transcription of pro-osteoclastogenic 

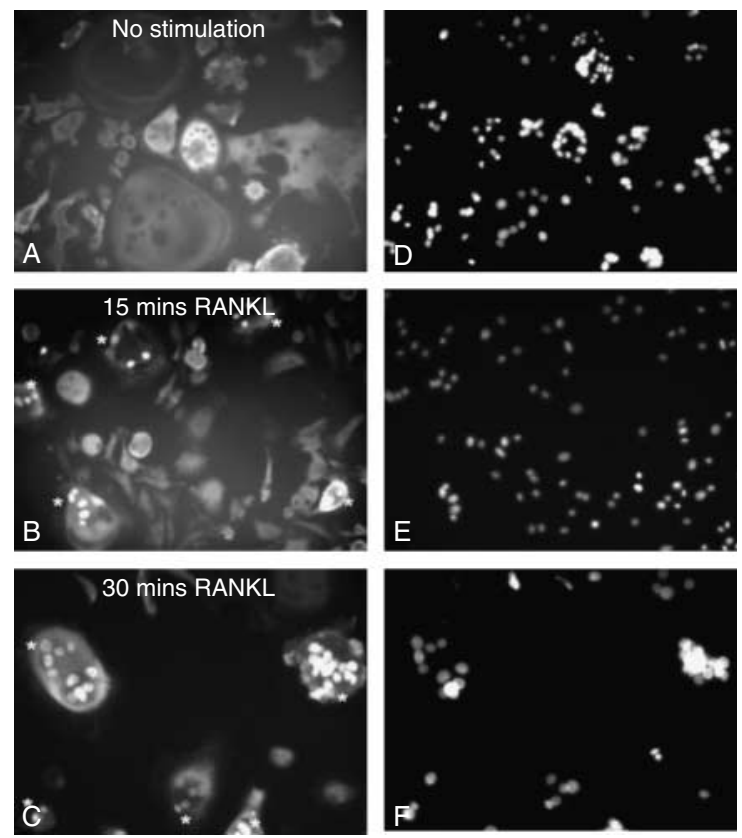

Figure $2 \mathrm{NF} \kappa \mathrm{B}$ translocates from the cytoplasm to the nucleus of osteoclasts when stimulated with RANKL. Human osteoclasts were serum starved for $3 \mathrm{~h}$ then stimulated with $50 \mathrm{ng} / \mathrm{ml} \mathrm{RANKL}$ for 0,15 and $30 \mathrm{~min}$. The cells were then fixed in $4 \%$ paraformaldehyde and immunostained for the NFKB family member p65 (A-C) and the nuclei counterstained with DAPI (D-F). Cells showing nuclear p65 are highlighted $\left(^{*}\right)$ in panels A-C.

genes (Wang et al. 2001) as shown in Fig. 3. In addition to $\mathrm{NF} \mathrm{B}, \mathrm{RANK}$ has been shown to activate MAP kinase signalling pathways through ERK1/2 and c-jun N-terminal kinase (JNK), which activate AP-1 transcription factors, and p38 which activates MITF (Lee \& Kim 2003) and thus regulates osteoclast differentiation. The $\mathrm{C}$-terminal tail of RANK recruits c-SRC which activates the family of $\mathrm{Cbl}$ proteins known to regulate osteoclast survival perhaps via regulation of RANK receptor recycling and degradation (Arron et al. 2001, Horne et al. 2005). These signalling molecules are also important for the activation of resorption, as discussed below. The target gene for NFKB and c-FOS in osteoclast precursors is NFATc1 (Fig. 3), the master transcription factor in osteoclastogenesis (Takayanagi et al. 2002). NFATc1 is induced early in osteoclast differentiation in response to increased levels of intracellular calcium that activate calcineurin. The exact mechanisms that lead to the rise in calcium levels are not known but may involve activation of PLC $\gamma$ and production of diacylglycerol and IP3 that releases calcium from the endoplasmic reticulum. Calcineurin is activated to dephosphorylate cytosolic NFATc1, which then translocates to the nucleus and regulates the expression of osteoclast-specific genes. NFATc1 binds in concert with PU.1 and MITF to the promoter regions of essential genes for osteoclast function encoding for proteins such as cathepsin K, OSCAR, DC-STAMP, TRAP and $\mathrm{V}-A T P a s e-d 2$. To further enhance the level of NFATc1 expression required to regulate osteoclast formation, NFATc1 also up-regulates its own expression in a process of autoamplification (Asagiri et al. 2005).

There are numerous factors that modulate RANKLstimulated osteoclast formation. Potentiators include immune factors such as tumour necrosis factor $\alpha$ (TNF $\alpha)$ and interleukin 1 (IL1). These factors are up-regulated in bonedestroying diseases such as rheumatoid arthritis associated with localised bone erosions (Adamopoulos et al. 2006). Inhibitors include osteoprotegerin (OPG; TNFRSF11B), a decoy receptor for RANKL and negative regulator of osteoclast formation in vivo (Simonet et al. 1997). Inactivating mutations in this gene cause Juvenile Paget's disease, a syndrome that is characterised by increased bone turnover featuring focal areas of increased bone remodelling (Whyte et al. 2002). In addition to the central and indispensible RANK signalling networks that regulate osteoclast formation, the whole process is also regulated by the activities of other important factors. For example, the ratio of two

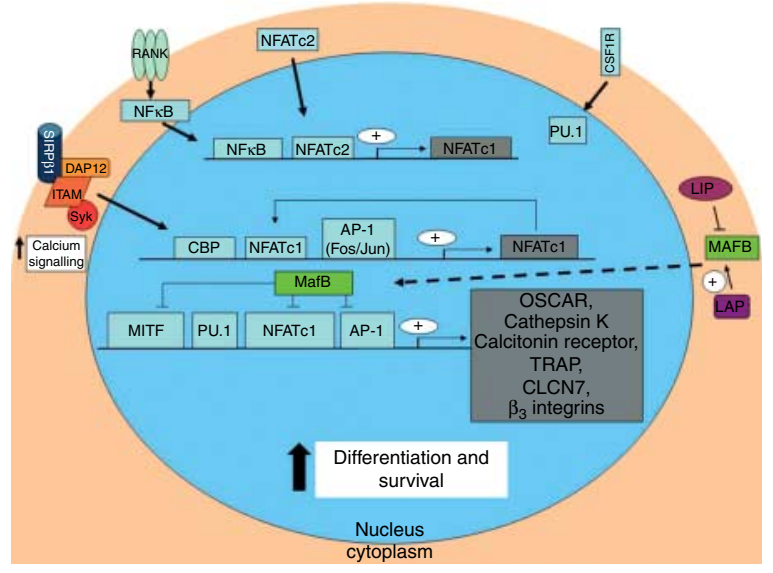

Figure 3 Upon activation of CSF1R and RANK, a number of proosteoclastic transcription factors are activated to up-regulate the expression of several genes critical for osteoclast differentiation and survival. Nuclear factor of activated T-cells, cytoplasmic 1 (NFATc1) is one of the main targets of RANK signalling and is strongly up-regulated following the binding of NFKB and NFATc2 to the NFATC1 promoter. NFATc1 expression is further enhanced by several other transcription factors including the members of the AP-1 complex and CREB-binding protein 1 (CBP) which is recruited via elevated cytosolic calcium levels. NFATc1 also undergoes autoamplification binding to its own promoter following the initial $\mathrm{NF \kappa B}$-induced expression. NFATc1 in conjunction with members of the AP-1 complex, microphthalmia-induced transcription factor (MITF) and PU.1 bind to promoter regions of several genes that encode proteins involved in osteoclast differentiation, function and survival including tartrate resistant acid phosphatase (TRAP), osteoclast-associated receptor (OSCAR), calcitonin receptor, cathepsin K, CLC-7 and $\beta_{3}$ integrins. Expression of these genes is tightly regulated and is down-regulated by MAFB. This factor inhibits the pro-osteoclastic transcription factors preventing them from binding to the promoter regions of target genes. The activity of MAFB is regulated by the ratio of LIP to LAP and when this ratio is altered in favour of LIP the activity of MAFB is inhibited and osteoclast gene expression is up-regulated. 
isoforms of the transcription coactivator $\mathrm{C} / \mathrm{EBP} \beta$ control osteoclast formation. The dominant short $\mathrm{C} / \mathrm{EBP} \beta$ isoform (LIP) has a shortened $\mathrm{N}$-terminus as a result of translation initiation from an alternative site. Translation from the alternative start site is dependent on the activation of mechanistic target of rapamycin (MTOR; also known as mammalian target of rapamycin, mTOR). The longer LAP isoform contains an $\mathrm{N}$-terminal transactivation domain that increases expression of MAFB that decreases osteoclast differentiation by inhibiting several pro-osteoclastic transcription factors including MITF, PU.1, NFATc1 and AP-1 (Kim et al. 2007). By contrast, LIP inhibits MAFB expression, allowing osteoclast formation to proceed. Therefore, through modulation of the MTOR signalling pathway, the ratio of LIP to LAP is altered (Fig. 3) and the level of osteoclastogenesis controlled (Smink et al. 2009).

Other regulators can be found in the CCN proteins, a family of secreted matrix proteins that act as multifunctional signalling regulators (Perbal 2004). CCN1 inhibits osteoclast formation in vitro (Crockett et al. 2007) via a mechanism that may involve a paracrine effect of osteoblast-derived CCN1 (Wang \& Crockett, unpublished observations) whereas CCN2 has been shown to be elevated in the serum and synovium of patients with rheumatoid arthritis where it is expressed in the synovial macrophages and is associated with increased osteoclast formation and activity (Nozawa et al. 2009), possibly as a consequence of regulating DC-STAMP expression (Nishida et al. 2011).

Reduced oxygen tension stimulates osteoclast formation in vitro with little or no direct effect on osteoclast activation. This may be important in the pathology of conditions that affect the vasculature resulting in reduced tissue perfusion, many of which are also associated with increased bone loss (Arnett et al. 2003). By contrast, acidification of cultures of mature osteoclasts in vitro leads to increased osteoclast activation, whilst reduced $\mathrm{pH}$ during the formation of osteoclasts does not affect osteoclast number (reviewed in Arnett (2010)). Extracellular nucleotides are also likely local regulators of osteoclast formation and/or activity since multiple $\mathrm{P} 2$ receptors including, $\mathrm{P} 2 \mathrm{Y} 1, \mathrm{P} 2 \mathrm{Y} 6$ and $\mathrm{P} 2 \mathrm{X} 7$, have been shown to play roles at different stages of the process in vitro (Hoebertz et al. 2001, Grol et al. 2009, Orriss et al. 2011b) and manipulation of receptor expression in vivo results in distinct bone phenotypes (Orriss et al. 2011a). However, the relative contribution of each receptor subtype to the overall maintenance of osteoclasts in vivo and indeed the coordinated process of bone remodelling is not yet known and there is likely to be redundancy between them (Orriss et al. 2010).

\section{Osteoclastic bone resorption}

Once formed, osteoclasts have the unique ability to destroy (resorb) mineralised bone as part of bone modelling in early life, or as part of remodelling during adult life (Crockett et al. 2011b). This process occurs in three stages: osteoclast attachment and polarisation, initiation of resorption and cessation of resorption (perhaps followed by cell death). The tight regulation of these stages is critical, since too much bone resorption leads to a reduction in the overall amount of bone such as found, for example, in postmenopausal osteoporosis. Too little resorption, on the other hand, causes osteopetrotic conditions where bone mass is high. Both high and low bone mass conditions can result in increased susceptibility to fractures, in the latter because there simply is too little bone and in the former because the bone quality and strength is poor. This high risk of fracture is perhaps the defining characteristic of bone diseases caused by deregulation of osteoclast activity since high bone mass conditions caused by increased osteoblast activity are not associated with increased risk of fracture.

\section{Initiating resorption}

When osteoclasts attach to bone, they develop integrinmediated adhesion structures called podosomes that are reorganised into a densely packed ring, the sealing zone (Jurdic et al. 2006, Luxenburg et al. 2007). This area of tight attachment to the extracellular matrix effectively seals off a compartment beneath the cell where bone degradation occurs (Luxenburg et al. 2007). Indeed as a result of polarised vesicular trafficking, the membrane enclosed by the sealing zone becomes a highly convoluted ruffled border, where protons and proteases are secreted to demineralise and degrade the bone matrix respectively (Fig. 4A; Lakkakorpi \& Väänänen 1996, Palokangas et al. 1997, Mulari et al. 2003a). Therefore, osteoclast adhesion mediated by the engagement of integrins and CD44 receptors induces signalling pathways necessary to initiate resorption.

Podosomes are formed by a core of densely packed actin filaments and F-actin-associated proteins such as cortactin, Wiskott-Aldrich syndrome proteins (WASp) and ARP2/3, surrounded by integrins and attachment-related proteins such as vinculin and talin as illustrated in Fig. 5 (Jurdic et al. 2006, Spinardi \& Marchisio 2006). These structures are highly dynamic and can assemble and disassemble within minutes in contrast to more stable structures of focal adhesions such as those seen in other cell types (Destaing et al. 2003, Block et al. 2008). Osteoclast attachment to the bone surface is mainly dependent on integrins, particularly the vitronectin receptor $\left(\alpha_{v} \beta_{3}\right)$, the most abundant integrin in osteoclasts (Davies et al. 1989, Nakamura et al. 1999, McHugh et al. 2000). The deletion of the $\beta_{3}$ subunit in mice has dramatic effects on osteoclast spreading, cytoskeletal organisation and activity, and, as expected, leads to a progressive osteopetrosis (McHugh et al. 2000). Upon binding to RGD motifcontaining ligands, such as vitronectin (Humphries et al. 2006), $\alpha_{v} \beta_{3}$ integrins recruit numerous proteins, including the non-receptor tyrosine kinases PYK2, SRC and SYK, as well as the ubiquitin ligase c-CBL (Duong et al. 1998, Sanjay et al. 2001, Zou et al. 2007). All members of this complex are involved in both podosome assembly and disassembly 


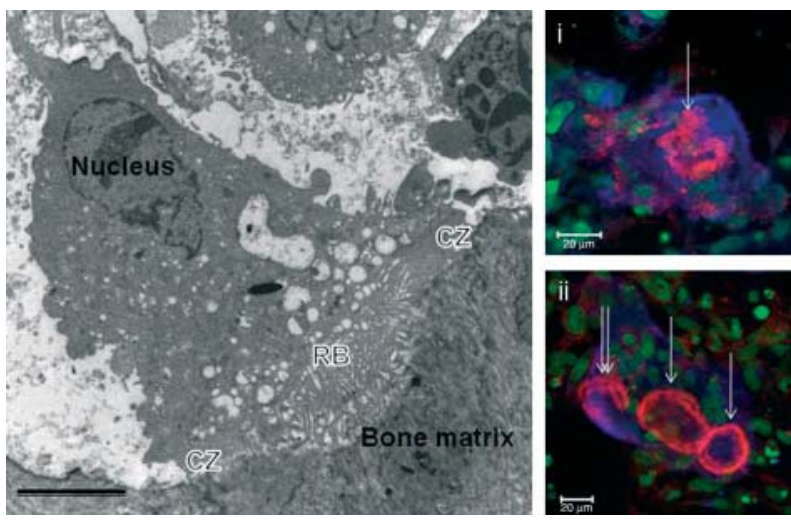

Figure 4 (Left panel) Transmission electron micrograph of an osteoclast illustrating its attachment to the bone surface. The clear zone $(\mathrm{CZ})$ rich in F-actin is indicated as is the ruffled border membrane (RB). Bar is $5 \mu \mathrm{m}$. The many proteins present in these membrane domains are detailed in Fig. 5. (Right panels) Confocal micrographs of immunofluorescently stained osteoclasts cultured on dentine, illustrating the formation of podosomes and F-actin rings. Osteoclasts were treated with calcitonin to disrupt attachment to bone and then allowed to repolarise. In i) cells have started to reform podosomes (arrow) and these are beginning to aggregate ( $2 \mathrm{~h}$ after removal of calcitonin) and ii) the osteoclast has reformed F-actin rings (single arrows), still reforming a third F-actin ring (double arrow) and is actively resorbing again ( $6 \mathrm{~h}$ after removal of calcitonin). Bar is $20 \mu \mathrm{m}$. Osteoclasts were seeded on slices of dentin (black) and stained for F-actin (red), plasma membrane (blue) and nuclei (green).

as well as podosome organisation (Horne et al. 2005, Zou \& Teitelbaum 2010).

The critical role of SRC in the assembly, organisation and stability of podosomes is underlined by the findings that osteoclasts derived from SRC-deficient mice, that have an osteopetrotic phenotype, have fewer podosomes (Destaing et al. 2008) and that SRC kinase activity is required for actin ring formation and resorption (Miyazaki et al. 2004). SRC kinases phosphorylate numerous substrates including cortactin and gelsolin that regulate actin polymerisation and podosome turnover (De Corte et al. 1997, Tehrani et al. 2007). Cortactin depletion leads to loss of podosomes that can be rescued by re-expressing wild-type cortactin in the cells, however no rescue was observed when a mutant of cortactin that cannot be phosphorylated by SRC was used (Tehrani et al. 2006). This demonstrates the importance of SRC phosphorylation for podosome formation. Similar to cortactin, gelsolin deficiency also inhibits podosome formation and osteoclast migration (Chellaiah et al. 2000). SRC also phosphorylates spleen tyrosine kinase (SYK), which leads to cytoskeletal reorganisation by promoting the activation of VAV3, a Rho family guanine exchange factor (Faccio et al. 2005), and subsequently of RAC and CDC42 (Itzstein et al. 2011, Teitelbaum \& Zou 2011). These small GTPases stimulate WASp and cortactin, known activators of the ARP2/3 complex that is required for actin nucleation and polymerisation (Higgs \& Pollard 2001, Weaver et al. 2001, Itzstein et al. 2011). M-CSF also plays a role in integrin signalling by promoting a change in conformation of $\beta_{3}$ integrin, increasing its affinity for ligand (Faccio et al. 2002, Teitelbaum \& Zou 2011) and by stimulating Rho familymediated cytoskeletal rearrangement (Faccio et al. 2005, Itzstein et al. 2011).

Recently, it was discovered that mutations in kindlin-3, a protein that activates integrins on blood-derived lymphocytes and platelets (Moser et al. 2008), result in osteopetrosis (Schmidt et al. 2011). Osteoclasts generated from mice deficient in kindlin-3 lack podosomes and are unable to activate signalling downstream of $\beta_{1}, \beta_{2}$ and $\beta_{3}$ integrins (Schmidt et al. 2011), confirming the major role of integrin signalling for osteoclast adhesion and polarisation.

Osteoclast attachment to bone matrix also involves the hyaluronic acid receptor CD44 that binds to osteopontin (Goodison et al. 1999). Similarly to integrin signalling, the stimulation of CD44 activates ARP2/3 complex and WASpinteracting protein (WIP) deficiency in osteoclasts leads to a loss of podosomes that can be rescued by osteopontin treatment (Chabadel et al. 2007), demonstrating that CD44mediated signalling pathways are required for podosome formation and osteoclast attachment to bone matrix.

Podosome rearrangement into a densely packed ring is critical for the formation of a sealing zone (Figs 4B and 5). Unlike osteoclasts seeded on plastic or glass, only osteoclasts plated on bone matrix form a sealing zone. Saltel et al. (2004) demonstrated that adhesion of osteoclasts to apatite matrix activates SRC and Rho signalling triggering the formation of the sealing zone. Indeed, this process is characterised by the stabilisation of the microtubule network (Destaing et al. 2005, Jurdic et al. 2006). In osteoclasts, deacetylation of microtubules by the histone deacetylase HDAC6 is promoted by increased RHO activity (Destaing et al. 2005) and leads to the disruption of the sealing zone. PYK2 down-regulates RHO activity to allow the stabilisation of the microtubules and the sealing zone (Gil-Henn et al. 2007). Recently, it has been demonstrated that CBL proteins protect microtubules from deacetylation by competing with HDAC6 for binding to $\beta$-tubulin (Purev et al. 2009).

The ruffled border (Figs 4A and 5) is formed by polarised transport of acidic vesicles of the endocytic/lysosomal pathway to allow the delivery of the resorption machinery such as cathepsin $\mathrm{K}$, vacuolar ATPase and the chloride/H+ antiporter CLC-7 to the plasma membrane in direct contact with bone (Coxon \& Taylor 2008). This vesicular trafficking is regulated by RAB small GTPases including RAB7 and $\mathrm{RAB} 3 \mathrm{D}$ since ruffled borders are absent in osteoclasts lacking either protein (Zhao et al. 2001, Pavlos et al. 2005, Itzstein et al. 2011). It has been hypothesised that the interaction of $\mathrm{RAB} 7$ with $\mathrm{RAC} 1$ is required for the transfer of vesicles from microtubules to cortical actin and their subsequent delivery and fusion to the plasma membrane (Sun et al. 2005, Frasa et al. 2010). The V-ATPase is also a potential mediator of this process via its direct binding to actin (Zuo et al. 2006) since mutations in the TCIRG1 gene which encodes the a3 subunit of V-ATPase cause osteopetrosis due not only to defects in 


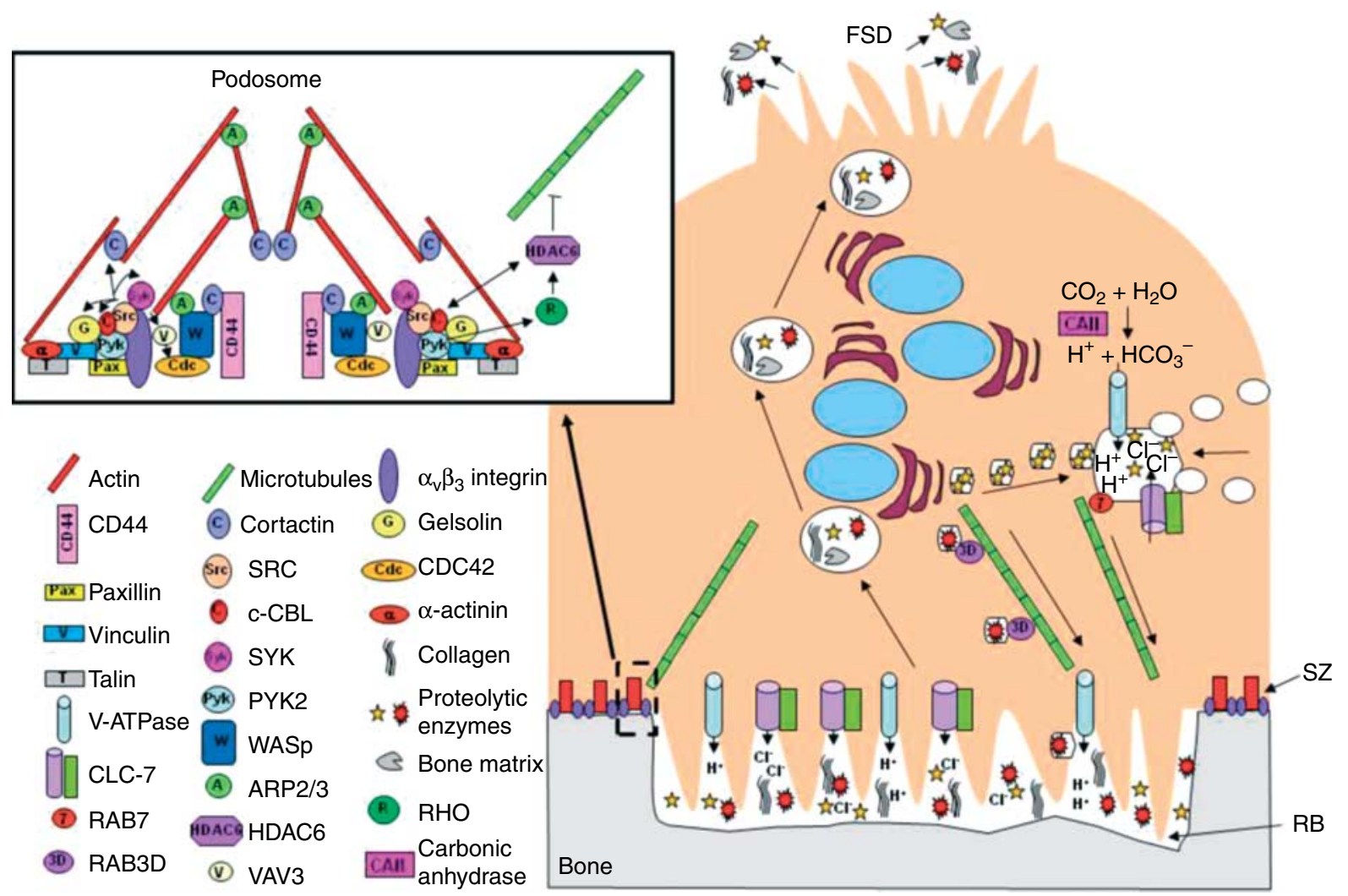

Figure 5 Podosomal signalling and vesicular trafficking pathways are necessary for osteoclast polarisation and resorption. Following contact with bone, the osteoclast becomes polarised and forms several distinct regions including the sealing zone (SZ), the ruffled border (RB) and the functional secretory domain (FSD). The ruffled border is a highly convoluted membrane that forms an isolated area where resorption of the bone matrix takes place. During polarisation, the osteoclast rearranges its actin cytoskeleton to form an F-actin ring (SZ) comprised of highly dynamic podosomes that facilitate its attachment and detachment to and from the bone surface. The formation of podosomes is induced by av3 $\beta$ integrin and CD44 signalling to activate SRC kinase and ARP2/3 complex, respectively, thereby regulating actin polymerisation. The regulation of RHO activity by PYK2 as well as the competition of CBL with HDAC6 to bind to $\beta$-tubulin allows the stabilisation of the microtubule network required for the SZ. The ruffled border provides a large surface area for the release of proteolytic enzymes (cathepsin K) and protons required for the degradation of the bone matrix. During resorption, acidic vesicles are targeted to the RB by RAB small GTPases and are inserted into the RB membrane where the vacuolar-type proton ATPase (V-ATPase) and chloride/H+ antiporter (CLC-7) transport protons and chloride ions whilst maintaining electroneutrality. The products of resorption are removed from the resorption area via transcytosis through the osteoclast where they are secreted across the FSD.

acidification of the resorption lacuna but also in ruffled border formation (Blair et al. 2004, Ochotny et al. 2011). The role for $\mathrm{RAB7}$ in ruffled border formation is also supported by the observation that RAB7 interacts with PLEKHM1, a large cytosolic protein in which mutations cause a loss of ruffled border resulting in osteopetrosis caused by dysfunctional osteoclasts (Van Wesenbeeck et al. 2007). The fusion of the vesicles to the plasma membrane could be mediated by synaptotagmin (SYT) proteins since osteoclasts lacking SYT VII have defects in ruffled border formation and cathepsin $\mathrm{K}$ secretion suggesting that this family of proteins regulate protease exocytosis at the ruffled border (Zhao et al. 2008).

Once degraded, bone matrix products are internalised by endocytosis in the central area of the ruffled border where vesicle coat proteins such as clathrin and adaptor protein complex 2 (AP-2) are localised as well as the GTPase dynamin that mediates pinching off of vesicles (Mulari et al. 2003b).
The vesicles are then targeted to the functional secretory domain (Fig. 5) in the centre of the basolateral domain to be secreted (Mulari et al. 2003a,b), however the regulation of this transcytosis process remains to be determined.

\section{Switching off resorption}

Osteoclasts are highly motile cells and migrate from one site of resorption to a new site. The capacity of the cells to fulfil this role is made possible by the ability to disassemble and reassemble their podosomes quickly. Indeed, high levels of phosphorylated cortactin in osteoclasts are associated with low levels of actin turnover whereas unphosphorylated cortactin is associated with increased podosome dynamics (Luxenburg et al. 2006). Cortactin may form a link between the podosomes and the microtubule network since a recent report suggests that it interacts with EB-1, a protein that is 
associated with the ' + ' ends of microtubules and regulates stabilisation of microtubules (Biosse-Duplan et al. 2011).

The exact signals that halt resorption by an individual osteoclast in order for it to move to another location are not known. As described above, control of resorption at all stages is required to maintain bone quantity and quality and there are a number of physiological and pharmacological regulators of this process. Calcitonin is a hormone that is released by the thyroid parafollicular C-cells in response to raised calcium levels in the circulation (normally maintained to within $2 \cdot 2-2 \cdot 6 \mathrm{mM}$ ). Although mature osteoclasts express calcitonin receptors and respond rapidly to calcitonin which reversibly inhibits osteoclast activity via activation of cAMP (Chambers \& Moore 1983, Hattersley \& Chambers 1991, reviewed in Inzerillo et al. (2002)) the exact physiological role for calcitonin in controlling resorption in humans is not known. Calcitonin is, however, a very useful tool with which to study the ultrastructural changes that occur during osteoclast activation (Fig. 4B). In postmenopausal osteoporosis, the overall balance of formation to resorption tips in favour of resorption resulting in low bone mineral density and increased occurrence of pathological fractures. This can be linked to the loss of oestrogen at this time since this sex hormone is likely to play a role in osteoclast survival and induces osteoclast apoptosis in vivo and in vitro (Hughes et al. 1996). The exact mechanisms by which oestrogen mediates these effects is not known but may be via a paracrine effect of oestrogen acting via oestrogen receptor-mediated expression of FAS-ligand on osteoblasts (Krum \& Brown 2008). Bone loss following the menopause can be prevented by treatment with potent nitrogen-containing bisphosphonates, a class of drugs that target to bone and inhibit bone resorption via inhibition of the mevalonate pathway (Rogers et al. 2010). This inhibition prevents the proper processing (prenylation) of small GTPases that, as described above, are absolutely critical for resorption (Itzstein et al. 2011). Strontium ranelate also prevents bone loss but in addition stimulates new bone formation and reduces the risk of osteoporotic fracture (Kanis et al. 2011). The mechanisms by which this divalent cation achieves this are not fully understood but may involve both calcium-sensing receptor dependent and independent processes that lead to osteoclast apoptosis and stimulate osteoblast differentiation (Fromigue $e t$ al. 2009, Hurtel-Lemaire et al. 2009, Caudrillier et al. 2010).

Although overall osteoclast survival is critically important to regulate the amount of resorption that takes place, the motility of a given osteoclast and how much bone resorption occurs at a given location is also important. How long does an osteoclast spend in one place? What signals instruct it to move on? In cultures of osteoclasts on dentine, rodent-derived osteoclasts form characteristic resorption trails clearly demonstrating their motile nature. It has long been suggested that when the extracellular calcium concentration increases above a critical level, following release from the bone surface, resorption is inhibited as a consequence of disruption of cytoskeletal structure (Miyauchi et al. 1990) and that this may involve preventing the release of phosphatases (reviewed in Zaidi et al. (2004)) or by induction of apoptosis (Lorget et al. 2000). In vitro, a rise in extracellular calcium results in a rise in cytosolic calcium that is released from intracellular stores and internalised across the plasma membrane, via activation of cell surface receptors that sense calcium. Although the mechanisms that sense this increase in extracellular calcium have not been confirmed, such receptors may include 1,4,5trisphosphate receptors (IP3R) or ryanodine receptors, that also regulate release of calcium from internal stores, as well as an extracellular calcium-sensing receptor (Zaidi et al. 2004). The calcium release from intracellular stores is likely mediated by nitric oxide (NO), produced by osteoblasts and by osteoclasts themselves and a known mediator of osteoclast motility and/or apoptosis (Yaroslavskiy et al. 2005). Via cGMP synthesis NO activates protein kinase $G$ that phosphorylates vasodilator-stimulated phosphoprotein (VASP), as part of the integrin complex and via SRC-family kinase activates the IP3R1 receptor on endoplasmic reticulum membranes. The subsequent increase in cytosolic calcium induces disassembly of the cytoskeleton (Miyauchi et al. 1990), possibly through activation of the calcium-dependent proteinase mu-calpain that is required for normal osteoclast motility (Marzia et al. 2006, Yaroslavskiy et al. 2007). This presumably enables the osteoclast to adopt a motile phenotype as it detaches from the bone surface. The calcium concentration surrounding the osteoclast would then be diluted, allowing the osteoclast to repolarise and assemble a new sealing zone. The matrix itself also plays a crucial role in the process of osteoclast detachment and reattachment since osteopontin, an extracellular bone matrix protein, has long been recognised as an autocrine factor to stimulate osteoclast migration via $\alpha_{\mathrm{v}} \beta_{3}$ and CD44 (Chellaiah \& Hruska 2003) and TRAP may act to dephosphorylate osteopontin, and regulate osteoclast migration (Ek-Rylander \& Andersson 2010).

\section{Conclusion}

Osteoclasts play a key role in the process of bone modelling and bone remodelling. The receptors and ligands essential for osteoclast formation, osteoclast fusion and osteoclast polarisation and resorption have been increasingly uncovered, aided by the discovery of critical genes involved in monogenic bone disorders and gene knockout technology. While receptor or ligand loss- or gain-of-function mutations, or indeed mutations in key components of their downstream signalling pathways, may lead to severe osteoclast phenotypes and hence severe bone disease such as osteopetrosis, more subtle differences in these pathways are likely to contribute to differences in bone mass in the general populations. Genomewide association studies have uncovered critical roles for many of the proteins discussed in this review in postmenopausal osteoporosis and other bone diseases (Kiel et al. 2007, Rivadeneira et al. 2009, Albagha et al. 2010). In addition, pathway analysis has revealed further links between bone mass 
and specific pathways such as autophagy (Zhang et al. 2010). We are some way off using this knowledge in a clinical setting, but our increasing understanding of the physiology of bone resorption and the aetiology of bone disease has been advanced substantially by these findings. We anticipate further advances as current studies are focusing specifically on the analysis of signalling pathways already known to be important in osteoclast biology, such as, for example, the RANK pathway and begin to analyse genetic variation in all genes involved in its downstream signalling (as shown in Fig. 1B), to determine their combined contribution to the development of bone disease. Overall, increased knowledge of osteoclast biology over the past decade has contributed to better understanding of bone biology and bone pathology and thereby identified a range of new targets to combat bone disease.

\section{Declaration of interest}

The authors declare that there is no conflict of interest that could be perceived as prejudicing the impartiality of the research reported.

\section{Funding}

The authors' work in this area is funded by grants from the Medical Research Council (\# G1000435), Arthritis Research UK (\#19531 and \#17285) and the Paget's Association.

\section{Acknowledgements}

We thank Mr John Greenhorn and Mrs Angela Duthie for technical support and Dr Lynne Hocking for critically reading the manuscript. The work of the applicants was supported by staff of the microscopy core facilities at our Institute (http://www.abdn.ac.uk/ims/histology/ and http://www.abdn.ac. uk/ims/microscopy/).

\section{References}

Adamopoulos IE, Danks L, Itonaga I, Locklin RM, Sabokbar A, Ferguson DJ \& Athanasou NA 2006 Stimulation of osteoclast formation by inflammatory synovial fluid. Virchows Archiv 449 69-77. (doi:10.1007/s00428006-0200-y)

Albagha OM, Visconti MR, Alonso N, Langston AL, Cundy T, Dargie R, Dunlop MG, Fraser WD, Hooper MJ, Isaia G et al. 2010 Genome-wide association study identifies variants at CSF1, OPTN and TNFRSF11A as genetic risk factors for Paget's disease of bone. Nature Genetics 42 520-524. (doi:10.1038/ng.562)

Andersen TL, Soe K, Sondergaard TE, Plesner T \& Delaisse JM 2010 Myeloma cell-induced disruption of bone remodelling compartments leads to osteolytic lesions and generation of osteoclast-myeloma hybrid cells. British Journal of Haematology 148 551-561. (doi:10.1111/j.1365-2141. 2009.07980.x)

Armstrong AP, Tometsko ME, Glaccum M, Sutherland CL, Cosman D \& Dougall WC 2002 A RANK/TRAF6-dependent signal transduction pathway is essential for osteoclast cytoskeletal organization and resorptive function. Journal of Biological Chemistry 277 44347-44356. (doi:10.1074/ jbc.M202009200)
Arnett TR 2010 Acidosis, hypoxia and bone. Archives of Biochemistry and Biophysics 503 103-109. (doi:10.1016/j.abb.2010.07.021)

Arnett TR, Gibbons DC, Utting JC, Orriss IR, Hoebertz A, Rosendaal M \& Meghji S 2003 Hypoxia is a major stimulator of osteoclast formation and bone resorption. Journal of Cellular Physiology 196 2-8. (doi:10.1002/jcp. 10321)

Arron JR, Vologodskaia M, Wong BR, Naramura M, Kim N, Gu H \& Choi Y 2001 A positive regulatory role for $\mathrm{Cbl}$ family proteins in tumor necrosis factor-related activation-induced cytokine (trance) and CD40L-mediated Akt activation. Journal of Biological Chemistry 276 30011-30017. (doi:10. 1074/jbc.M100414200)

Asagiri M, Sato K, Usami T, Ochi S, Nishina H, Yoshida H, Morita I, Wagner EF, Mak TW, Serfling E et al. 2005 Autoamplification of NFATc1 expression determines its essential role in bone homeostasis. Journal of Experimental Medicine 202 1261-1269. (doi:10.1084/jem.20051150)

Bakiri L, Takada Y, Radolf M, Eferl R, Yaniv M, Wagner EF \& Matsuo K 2007 Role of heterodimerization of c-Fos and Fra1 proteins in osteoclast differentiation. Bone 40 867-875. (doi:10.1016/j.bone.2006.11.005)

Biosse-Duplan M, Stephens S, Lai FPL, Oelkers M, Rottner K, Horne WC \& Baron R 2011 In osteoclasts, dynamic microtubules and their assoicated protein EB1 control podosomes and bone resorption through cortactin. Bone 48 (Suppl 2) S97. (doi:10.1016/j.bone.2011.03.141)

Blair HC, Borysenko CW, Villa A, Schlesinger PH, Kalla SE, Yaroslavskiy BB, Garcia-Palacios V, Oakley JI \& Orchard PJ 2004 In vitro differentiation of CD14 cells from osteopetrotic subjects: contrasting phenotypes with TCIRG1, CLCN7, and attachment defects. Journal of Bone and Mineral Research 19 1329-1338. (doi:10.1359/JBMR.040403)

Block MR, Badowski C, Millon-Fremillon A, Bouvard D, Bouin AP, Faurobert E, Gerber-Scokaert D, Planus E \& Albiges-Rizo C 2008 Podosome-type adhesions and focal adhesions, so alike yet so different. European Journal of Cell Biology 87 491-506. (doi:10.1016/j.ejcb.2008.02. 012)

Caudrillier A, Hurtel-Lemaire AS, Wattel A, Cournarie F, Godin C, Petit L, Petit JP, Terwilliger E, Kamel S, Brown EM et al. 2010 Strontium ranelate decreases receptor activator of nuclear factor-kappa B ligand-induced osteoclastic differentiation in vitro: involvement of the calcium-sensing receptor. Molecular Pharmacology 78 569-576. (doi:10.1124/mol.109. 063347)

Chabadel A, Banon-Rodriguez I, Cluet D, Rudkin BB, Wehrle-Haller B, Genot E, Jurdic P, Anton IM \& Saltel F 2007 CD44 and beta3 integrin organize two functionally distinct actin-based domains in osteoclasts. Molecular Biology of the Cell 18 4899-4910. (doi:10.1091/mbc.E07-040378)

Chambers TJ \& Moore A 1983 The sensitivity of isolated osteoclasts to morphological transformation by calcitonin. Journal of Clinical Endocrinology and Metabolism 57 819-824. (doi:10.1210/jcem-57-4-819)

Chellaiah MA \& Hruska KA 2003 The integrin alpha(v)beta(3) and CD44 regulate the actions of osteopontin on osteoclast motility. Calcified Tissue International 72 197-205. (doi:10.1007/s00223-002-1025-6)

Chellaiah MA, Soga N, Swanson S, McAllister S, Alvarez U, Wang D, Dowdy SF \& Hruska KA 2000 Rho-A is critical for osteoclast podosome organization, motility, and bone resorption. Journal of Biological Chemistry 275 11993-12002. (doi:10.1074/jbc.275.16.11993)

Coxon FP \& Taylor A 2008 Vesicular trafficking in osteoclasts. Seminars in Cell and Developmental Biology 19 424-433. (doi:10.1016/j.semcdb.2008.08. 004)

Crockett JC, Schutze N, Tosh D, Jatzke S, Duthie A, Jakob F \& Rogers MJ 2007 The matricellular protein CYR61 inhibits osteoclastogenesis by a mechanism independent of alphavbeta3 and alphavbeta5. Endocrinology 148 5761-5768. (doi:10.1210/en.2007-0473)

Crockett JC, Mellis DJ, Scott DI \& Helfrich MH 2011a New knowledge on critical osteoclast formation and activation pathways from study of rare genetic diseases of osteoclasts: focus on the RANK/RANKL axis. Osteoporosis International 22 1-20. (doi:10.1007/s00198-010-1272-8)

Crockett JC, Rogers MJ, Coxon FP, Hocking LJ \& Helfrich MH $2011 b$ Bone remodelling at a glance. Journal of Cell Science 124 991-998. (doi:10.1242/ jcs.063032) 
Dai XM, Ryan GR, Hapel AJ, Dominguez MG, Russell RG, Kapp S, Sylvestre V \& Stanley ER 2002 Targeted disruption of the mouse colonystimulating factor 1 receptor gene results in osteopetrosis, mononuclear phagocyte deficiency, increased primitive progenitor cell frequencies, and reproductive defects. Blood 99 111-120. (doi:10.1182/blood.V99.1.111)

Darnay BG, Ni J, Moore PA \& Aggarwal BB 1999 Activation of NF-kappaB by RANK requires tumor necrosis factor receptor-associated factor (TRAF) 6 and NF-kappaB-inducing kinase. Identification of a novel TRAF6 interaction motif. Journal of Biological Chemistry 274 7724-7731. (doi:10.1074/jbc.274.12.7724)

Davies J, Warwick J, Totty N, Philp R, Helfrich M \& Horton M 1989 The osteoclast functional antigen, implicated in the regulation of bone resorption, is biochemically related to the vitronectin receptor. Journal of Cell Biology 109 1817-1826. (doi:10.1083/jcb.109.4.1817)

De Corte V, Gettemans J \& Vandekerckhove J 1997 Phosphatidylinositol 4,5bisphosphate specifically stimulates PP60(c-src) catalyzed phosphorylation of gelsolin and related actin-binding proteins. FEBS Letters 401 191-196. (doi:10.1016/S0014-5793(96)01471-8)

DeKoter RP, Walsh JC \& Singh H 1998 PU.1 regulates both cytokinedependent proliferation and differentiation of granulocyte/macrophage progenitors. EMBO Journal 17 4456-4468. (doi:10.1093/emboj/17.15. 4456)

Destaing O, Saltel F, Geminard JC, Jurdic P \& Bard F 2003 Podosomes display actin turnover and dynamic self-organization in osteoclasts expressing actingreen fluorescent protein. Molecular Biology of the Cell 14 407-416. (doi:10. 1091/mbc.E02-07-0389)

Destaing O, Saltel F, Gilquin B, Chabadel A, Khochbin S, Ory S \& Jurdic P 2005 A novel Rho-mDia2-HDAC6 pathway controls podosome patterning through microtubule acetylation in osteoclasts. Journal of Cell Science 118 2901-2911. (doi:10.1242/jcs.02425)

Destaing O, Sanjay A, Itzstein C, Horne WC, Toomre D, De Camilli P \& Baron R 2008 The tyrosine kinase activity of c-Src regulates actin dynamics and organization of podosomes in osteoclasts. Molecular Biology of the Cell 19 394-404. (doi:10.1091/mbc.E07-03-0227)

Dougall WC, Glaccum M, Charrier K, Rohrbach K, Brasel K, De Smedt T, Daro E, Smith J, Tometsko ME, Maliszewski CR et al. 1999 RANK is essential for osteoclast and lymph node development. Genes and Development 13 2412-2424. (doi:10.1101/gad.13.18.2412)

Duong LT, Lakkakorpi PT, Nakamura I, Machwate M, Nagy RM \& Rodan GA 1998 PYK2 in osteoclasts is an adhesion kinase, localized in the sealing zone, activated by ligation of alpha(v)beta 3 integrin, and phosphorylated by src kinase. Journal of Clinical Investigation 102 881-892. (doi:10.1172/ JCI3212)

Edwards CM \& Mundy GR 2008 Eph receptors and ephrin signaling pathways: a role in bone homeostasis. International Journal of Medical Sciences 5 263-272.

Ek-Rylander B \& Andersson G 2010 Osteoclast migration on phosphorylated osteopontin is regulated by endogenous tartrate-resistant acid phosphatase. Experimental Cell Research 316 443-451. (doi:10.1016/j.yexcr.2009.10.019)

Everts V, de Vries TJ \& Helfrich MH 2009 Osteoclast heterogeneity: lessons from osteopetrosis and inflammatory conditions. Biochimica et Biophysica Acta 1792 757-765. (doi:10.1016/j.bbadis.2009.05.004)

Faccio R, Grano M, Colucci S, Villa A, Giannelli G, Quaranta V \& Zallone A 2002 Localization and possible role of two different alpha $\mathrm{v}$ beta 3 integrin conformations in resting and resorbing osteoclasts. Journal of Cell Science 115 2919-2929.

Faccio R, Teitelbaum SL, Fujikawa K, Chappel J, Zallone A, Tybulewicz VL, Ross FP \& Swat W 2005 Vav3 regulates osteoclast function and bone mass. Nature Medicine 11 284-290. (doi:10.1038/nm1194)

Felix R, Cecchini MG \& Fleisch H 1990a Macrophage colony stimulating factor restores in vivo bone resorption in the op/op osteopetrotic mouse. Endocrinology 127 2592-2594. (doi:10.1210/endo-127-5-2592)

Felix R, Cecchini MG, Hofstetter W, Elford PR, Stutzer A \& Fleisch H $1990 b$ Impairment of macrophage colony-stimulating factor production and lack of resident bone marrow macrophages in the osteopetrotic op/op mouse. Journal of Bone and Mineral Research 5 781-789. (doi:10.1002/jbmr. 5650050716)
Franzoso G, Carlson L, Xing L, Poljak L, Shores EW, Brown KD, Leonardi A, Tran T, Boyce BF \& Siebenlist U 1997 Requirement for NF-kappaB in osteoclast and B-cell development. Genes and Development 11 3482-3496. (doi:10.1101/gad.11.24.3482)

Frasa MA, Maximiano FC, Smolarczyk K, Francis RE, Betson ME, Lozano E, Goldenring J, Seabra MC, Rak A, Ahmadian MR et al. 2010 Armus is a Rac1 effector that inactivates Rab7 and regulates E-cadherin degradation. Current Biology 20 198-208. (doi:10.1016/j.cub.2009.12.053)

Fromigue O, Hay E, Barbara A, Petrel C, Traiffort E, Ruat M \& Marie PJ 2009 Calcium sensing receptor-dependent and receptor-independent activation of osteoblast replication and survival by strontium ranelate. Journal of Cellular and Molecular Medicine 13 2189-2199. (doi:10.1111/ j.1582-4934.2008.00673.x)

Galibert L, Tometsko ME, Anderson DM, Cosman D \& Dougall WC 1998 The involvement of multiple tumor necrosis factor receptor (TNFR)associated factors in the signaling mechanisms of receptor activator of NF-kappaB, a member of the TNFR superfamily. Journal of Biological Chemistry 273 34120-34127. (doi:10.1074/jbc.273.51.34120)

Gil-Henn H, Destaing O, Sims NA, Aoki K, Alles N, Neff L, Sanjay A, Bruzzaniti A, De Camilli P, Baron R et al. 2007 Defective microtubuledependent podosome organization in osteoclasts leads to increased bone density in Pyk2(-/-) mice. Journal of Cell Biology 178 1053-1064. (doi:10.1083/jcb.200701148)

Goodison S, Urquidi V \& Tarin D 1999 CD44 cell adhesion molecules. Molecular Pathology 52 189-196. (doi:10.1136/mp.52.4.189)

Grigoriadis AE, Wang ZQ, Cecchini MG, Hofstetter W, Felix R, Fleisch HA \& Wagner EF 1994 c-Fos: a key regulator of osteoclast-macrophage lineage determination and bone remodeling. Science 266 443-448. (doi:10.1126/ science.7939685)

Grol MW, Panupinthu N, Korcok J, Sims SM \& Dixon SJ 2009 Expression, signaling, and function of $\mathrm{P} 2 \mathrm{X} 7$ receptors in bone. Purinergic Signalling $\mathbf{5}$ 205-221. (doi:10.1007/s11302-009-9139-1)

Guerrini MM, Sobacchi C, Cassani B, Abinun M, Kilic SS, Pangrazio A, Moratto D, Mazzolari E, Clayton-Smith J, Orchard P et al. 2008 Human osteoclast-poor osteopetrosis with hypogammaglobulinemia due to TNFRSF11A (RANK) mutations. American Journal of Human Genetics 83 64-76. (doi:10.1016/j.ajhg.2008.06.015)

Hattersley G \& Chambers TJ 1991 Calcitonin receptors as markers for osteoclastic differentation: correlation between generation of bone resorptive cells and cells that express calcitonin receptors in mouse bone marrow cultures. Endocrinology 128 1606-1612. (doi:10.1210/endo128-1-259)

Helfrich MH, Mieremet RHP \& Thesingh CW 1989 Osteoclast formation in vitro from progenitor cells present in the adult mouse circulation. Journal of Bone and Mineral Research 4 325-334. (doi:10.1002/jbmr.5650040306)

Higgs HN \& Pollard TD 2001 Regulation of actin filament network formation through ARP2/3 complex: activation by a diverse array of proteins. Annual Review of Biochemistry 70 649-676. (doi:10.1146/annurev. biochem.70.1.649)

Hoebertz A, Meghji S, Burnstock G \& Arnett TR 2001 Extracellular ADP is a powerful osteolytic agent: evidence for signaling through the $\mathrm{P} 2 \mathrm{Y}(1)$ receptor on bone cells. FASEB Journal 15 1139-1148. (doi:10.1096/fj.00$0395 \mathrm{com})$

Horne WC, Sanjay A, Bruzzaniti A \& Baron R 2005 The role(s) of Src kinase and $\mathrm{Cbl}$ proteins in the regulation of osteoclast differentiation and function. Immunological Reviews 208 106-125. (doi:10.1111/j.0105-2896.2005. 00335.x)

Hsu H, Lacey DL, Dunstan CR, Solovyev I, Colombero A, Timms E, Tan HL, Elliott G, Kelley MJ, Sarosi I et al. 1999 Tumor necrosis factor receptor family member RANK mediates osteoclast differentiation and activation induced by osteoprotegerin ligand. PNAS 96 3540-3545. (doi:10.1073/ pnas.96.7.3540)

Hu R, Sharma SM, Bronisz A, Srinivasan R, Sankar U \& Ostrowski MC 2007 Eos, MITF, and PU.1 recruit corepressors to osteoclast-specific genes in committed myeloid progenitors. Molecular and Cellular Biology 27 4018-4027. (doi:10.1128/MCB.01839-06) 
Hughes DE, Dai A, Tiffee JC, Li HH, Mundy GR \& Boyce BF 1996 Estrogen promotes apoptosis of murine osteoclasts mediated by TGF-beta. Nature Medicine 2 1132-1136. (doi:10.1038/nm1096-1132)

Humphries JD, Byron A \& Humphries MJ 2006 Integrin ligands at a glance. Journal of Cell Science 119 3901-3903. (doi:10.1242/jcs.03098)

Hurtel-Lemaire AS, Mentaverri R, Caudrillier A, Cournarie F, Wattel A, Kamel S, Terwilliger EF, Brown EM \& Brazier M 2009 The calciumsensing receptor is involved in strontium ranelate-induced osteoclast apoptosis. New insights into the associated signaling pathways. Journal of Biological Chemistry 284 575-584. (doi:10.1074/jbc.M801668200)

Inzerillo AM, Zaidi M \& Huang CL 2002 Calcitonin: the other thyroid hormone. Thyroid 12 791-798. (doi:10.1089/105072502760339352)

Iotsova V, Caamano J, Loy J, Yang Y, Lewin A \& Bravo R 1997 Osteopetrosis in mice lacking NF-kappaB1 and NF-kappaB2. Nature Medicine 3 1285-1289. (doi:10.1038/nm1197-1285)

Ishii J, Kitazawa R, Mori K, McHugh KP, Morii E, Kondo T \& Kitazawa S 2008 Lipopolysaccharide suppresses RANK gene expression in macrophages by down-regulating PU.1 and MITF. Journal of Cellular Biochemistry 105 896-904. (doi:10.1002/jcb.21886)

Itzstein C, Coxon FP \& Rogers MJ 2011 The regulation of osteoclast function and bone resorption by small GTPases. Small GTPases 2 117-130. (doi:10. 4161/sgtp.2.3.16453)

Jurdic P, Saltel F, Chabadel A \& Destaing O 2006 Podosome and sealing zone: specificity of the osteoclast model. European Journal of Cell Biology $\mathbf{8 5}$ 195-202. (doi:10.1016/j.ejcb.2005.09.008)

Kanis JA, Johansson H, Oden A \& McCloskey EV 2011 A meta-analysis of the effect of strontium ranelate on the risk of vertebral and non-vertebral fracture in postmenopausal osteoporosis and the interaction with FRAX((R)). Osteoporosis International 22 2347-2355. (doi:10.1007/s00198010-1474-0)

Kiel DP, Demissie S, Dupuis J, Lunetta KL, Murabito JM \& Karasik D 2007 Genome-wide association with bone mass and geometry in the Framingham Heart Study. BMC Medical Genetics 8 (Suppl 1) S14. (doi:10. 1186/1471-2350-8-S1-S14)

Kim K, Kim JH, Lee J, Jin HM, Lee SH, Fisher DE, Kook H, Kim KK, Choi Y \& Kim N 2005 Nuclear factor of activated T cells c1 induces osteoclastassociated receptor gene expression during tumor necrosis factor-related activation-induced cytokine-mediated osteoclastogenesis. Journal of Biological Chemistry 280 35209-35216. (doi:10.1074/jbc.M505815200)

Kim K, Kim JH, Lee J, Jin HM, Kook H, Kim KK, Lee SY \& Kim N 2007 MafB negatively regulates RANKL-mediated osteoclast differentiation. Blood 109 3253-3259. (doi:10.1182/blood-2006-09-048249)

Kong YY, Yoshida H, Sarosi I, Tan HL, Timms E, Capparelli C, Morony S, Oliveira-dos-Santos AJ, Van G, Itie A et al. 1999 OPGL is a key regulator of osteoclastogenesis, lymphocyte development and lymph-node organogenesis. Nature 397 315-323. (doi:10.1038/16852)

Krum SA \& Brown M 2008 Unraveling estrogen action in osteoporosis. Cell Cycle 7 1348-1352. (doi:10.4161/cc.7.10.5892)

Kwon OH, Lee CK, Lee YI, Paik SG \& Lee HJ 2005 The hematopoietic transcription factor PU.1 regulates RANK gene expression in myeloid progenitors. Biochemical and Biophysical Research Communications 335 437-446. (doi:10.1016/j.bbrc.2005.07.092)

Lagasse E \& Weissman IL 1997 Enforced expression of Bcl-2 in monocytes rescues macrophages and partially reverses osteopetrosis in op/op mice. Cell 89 1021-1031. (doi:10.1016/S0092-8674(00)80290-1)

Lakkakorpi PT \& Väänänen HK 1996 Cytoskeletal changes in osteoclasts during the resorption cycle. Microscopy Research and Technique 33 171-181. (doi:10.1002/(SICI)1097-0029(19960201)33:2<171::AID-JEMT7>3.0. $\mathrm{CO} ; 2-\mathrm{W})$

Lee ZH \& Kim HH 2003 Signal transduction by receptor activator of nuclear factor kappa B in osteoclasts. Biochemical and Biophysical Research Communications 305 211-214. (doi:10.1016/S0006-291X(03)00695-8)

Lomaga MA, Yeh WC, Sarosi I, Duncan GS, Furlonger C, Ho A, Morony S, Capparelli C, Van G, Kaufman S et al. 1999 TRAF6 deficiency results in osteopetrosis and defective interleukin-1, CD40, and LPS signaling. Genes and Development 13 1015-1024. (doi:10.1101/gad.13.8.1015)
Lorget F, Kamel S, Mentaverri R, Wattel A, Naassila M, Maamer M \& Brazier M 2000 High extracellular calcium concentrations directly stimulate osteoclast apoptosis. Biochemical and Biophysical Research Communications 268 899-903. (doi:10.1006/bbrc.2000.2229)

Lu SY, Li M \& Lin YL 2010 Mitf induction by RANKL is critical for osteoclastogenesis. Molecular Biology of the Cell 21 1763-1771. (doi:10.1091/ mbc.E09-07-0584)

Luchin A, Purdom G, Murphy K, Clark MY, Angel N, Cassady AI, Hume DA \& Ostrowski MC 2000 The microphthalmia transcription factor regulates expression of the tartrate-resistant acid phosphatase gene during terminal differentiation of osteoclasts. Journal of Bone and Mineral Research 15 451-460. (doi:10.1359/jbmr.2000.15.3.451)

Luchin A, Suchting S, Merson T, Rosol TJ, Hume DA, Cassady AI \& Ostrowski MC 2001 Genetic and physical interactions between microphthalmia transcription factor and PU.1 are necessary for osteoclast gene expression and differentiation. Journal of Biological Chemistry 276 36703-36710. (doi:10.1074/jbc.M106418200)

Luxenburg C, Parsons JT, Addadi L \& Geiger B 2006 Involvement of the Srccortactin pathway in podosome formation and turnover during polarization of cultured osteoclasts. Journal of Cell Science 119 4878-4888. (doi:10.1242/ jcs.03271)

Luxenburg C, Geblinger D, Klein E, Anderson K, Hanein D, Geiger B \& Addadi L 2007 The architecture of the adhesive apparatus of cultured osteoclasts: from podosome formation to sealing zone assembly. PLoS ONE 2 e179. (doi:10.1371/journal.pone.0000179)

Marzia M, Chiusaroli R, Neff L, Kim NY, Chishti AH, Baron R \& Horne WC 2006 Calpain is required for normal osteoclast function and is downregulated by calcitonin. Journal of Biological Chemistry 281 9745-9754. (doi:10.1074/jbc.M513516200)

Matsumoto M, Kogawa M, Wada S, Takayanagi H, Tsujimoto M, Katayama S, Hisatake K \& Nogi Y 2004 Essential role of p38 mitogen-activated protein kinase in cathepsin $\mathrm{K}$ gene expression during osteoclastogenesis through association of NFATc1 and PU.1. Journal of Biological Chemistry 279 45969-45979. (doi:10.1074/jbc.M408795200)

McGill GG, Horstmann M, Widlund HR, Du J, Motyckova G, Nishimura EK, Lin YL, Ramaswamy S, Avery W, Ding HF et al. $2002 \mathrm{Bcl} 2$ regulation by the melanocyte master regulator Mitf modulates lineage survival and melanoma cell viability. Cell 109 707-718. (doi:10.1016/S0092-8674 (02)00762-6)

McHugh KP, Hodivala-Dilke K, Zheng MH, Namba N, Lam J, Novack D, Feng X, Ross FP, Hynes RO \& Teitelbaum SL 2000 Mice lacking beta3 integrins are osteosclerotic because of dysfunctional osteoclasts. Journal of Clinical Investigation 105 433-440. (doi:10.1172/JCI8905)

Miyauchi A, Hruska KA, Greenfield EM, Duncan R, Alvarez J, Barattolo R, Colucci S, Zamboninzallone A, Teitelbaum SL \& Teti A 1990 Osteoclast cytosolic calcium, regulated by voltage-gated calcium channels and extracellular calcium, controls podosome assembly and bone-resorption. Journal of Cell Biology 111 2543-2552. (doi:10.1083/jcb.111.6.2543)

Miyazaki T, Sanjay A, Neff L, Tanaka S, Horne WC \& Baron R 2004 Src kinase activity is essential for osteoclast function. Journal of Biological Chemistry 279 17660-17666. (doi:10.1074/jbc.M311032200)

Moser M, Nieswandt B, Ussar S, Pozgajova M \& Fassler R 2008 Kindlin-3 is essential for integrin activation and platelet aggregation. Nature Medicine 14 325-330. (doi:10.1038/nm1722)

Motyckova G, Weilbaecher KN, Horstmann M, Rieman DJ, Fisher DZ \& Fisher DE 2001 Linking osteopetrosis and pycnodysostosis: regulation of cathepsin $\mathrm{K}$ expression by the microphthalmia transcription factor family. PNAS 98 5798-5803. (doi:10.1073/pnas.091479298)

Mulari M, Vaaraniemi J \& Väänänen HK 2003a Intracellular membrane trafficking in bone resorbing osteoclasts. Microscopy Research and Technique 61 496-503. (doi:10.1002/jemt.10371)

Mulari MT, Zhao H, Lakkakorpi PT \& Väänänen HK 2003b Osteoclast ruffled border has distinct subdomains for secretion and degraded matrix uptake. Traffic 4 113-125. (doi:10.1034/j.1600-0854.2003.40206.x)

Murphy HM 1973 The osteopetrotic syndrome in the microphthalmic mutant mouse. Calcified Tissue Research 13 19-26. (doi:10.1007/ BF02015392) 
Nakamura I, Pilkington MF, Lakkakorpi PT, Lipfert L, Sims SM, Dixon SJ, Rodan GA \& Duong LT 1999 Role of alpha(v)beta(3) integrin in osteoclast migration and formation of the sealing zone. Journal of Cell Science $\mathbf{1 1 2}$ 3985-3993.

Nishida T, Emura K, Kubota S, Lyons KM \& Takigawa M 2011 CCN family $2 /$ connective tissue growth factor (CCN2/CTGF) promotes osteoclastogenesis via induction of and interaction with dendritic cell-specific transmembrane protein (DC-STAMP). Journal of Bone and Mineral Research 26 351-363. (doi:10.1002/jbmr.222)

Nozawa K, Fujishiro M, Kawasaki M, Kaneko H, Iwabuchi K, Yanagida M, Suzuki F, Miyazawa K, Takasaki Y, Ogawa H et al. 2009 Connective tissue growth factor promotes articular damage by increased osteoclastogenesis in patients with rheumatoid arthritis. Arthritis Research \& Therapy 11 R174. (doi:10.1186/ar2863)

Ochotny N, Flenniken AM, Owen C, Voronov I, Zirngibl RA, Osborne LR, Henderson JE, Adamson SL, Rossant J, Manolson MF et al. 2011 The V-ATPase a3 subunit mutation R740S is dominant negative and results in osteopetrosis in mice. Journal of Bone and Mineral Research 26 1484-1493. (doi:10.1002/jbmr.355)

Orriss IR, Burnstock G \& Arnett TR 2010 Purinergic signalling and bone remodelling. Current Opinion in Pharmacology 10 322-330. (doi:10.1016/j. coph.2010.01.003)

Orriss I, Syberg S, Wang N, Robaye B, Gartland A, Jorgensen N, Arnett T \& Boeynaems JM 2011a Bone phenotypes of P2 receptor knockout mice. Frontiers in Bioscience 3 1038-1046. (doi:10.2741/208)

Orriss IR, Wang N, Burnstock G, Arnett TR, Gartland A, Robaye B \& Boeynaems JM $2011 b$ The P2Y6 receptor stimulates bone resorption by osteoclasts. Endocrinology 152 3706-3716. (doi:10.1210/en.2011-1073)

Palokangas H, Mulari M \& Vaananen HK 1997 Endocytic pathway from the basal plasma membrane to the ruffled border membrane in bone-resorbing osteoclasts. Journal of Cell Science 110 1767-1780.

Pavlos NJ, Xu J, Riedel D, Yeoh JS, Teitelbaum SL, Papadimitriou JM, Jahn R, Ross FP \& Zheng MH 2005 Rab3D regulates a novel vesicular trafficking pathway that is required for osteoclastic bone resorption. Molecular and Cellular Biology 25 5253-5269. (doi:10.1128/MCB.25.12.5253-5269. 2005)

Perbal B 2004 CCN proteins: multifunctional signalling regulators. Lancet 363 62-64. (doi:10.1016/S0140-6736(03)15172-0)

Purev E, Neff L, Horne WC \& Baron R 2009 c-Cbl and Cbl-b act redundantly to protect osteoclasts from apoptosis and to displace HDAC6 from beta-tubulin, stabilizing microtubules and podosomes. Molecular Biology of the Cell 20 4021-4030. (doi:10.1091/mbc.E09-03-0248)

Rivadeneira F, Styrkarsdottir U, Estrada K, Halldorsson BV, Hsu YH, Richards JB, Zillikens MC, Kavvoura FK, Amin N, Aulchenko YS et al. 2009 Twenty bone-mineral-density loci identified by large-scale metaanalysis of genome-wide association studies. Nature Genetics 41 1199-1206. (doi:10.1038/ng.446)

Rogers MJ, Crockett JC, Coxon FP \& Monkkonen J 2010 Biochemical and molecular mechanisms of action of bisphosphonates. Bone 49 34-41. (doi:10.1016/j.bone.2010.11.008)

Saltel F, Destaing O, Bard F, Eichert D \& Jurdic P 2004 Apatite-mediated actin dynamics in resorbing osteoclasts. Molecular Biology of the Cell $\mathbf{1 5}$ 5231-5241. (doi:10.1091/mbc.E04-06-0522)

Sanjay A, Houghton A, Neff L, DiDomenico E, Bardelay C, Antoine E, Levy J, Gailit J, Bowtell D, Horne WC et al. $2001 \mathrm{Cbl}$ associates with Pyk2 and $\mathrm{Src}$ to regulate Src kinase activity, alpha(v)beta(3) integrin-mediated signaling, cell adhesion, and osteoclast motility. Journal of Cell Biology $\mathbf{1 5 2}$ 181-195. (doi:10.1083/jcb.152.1.181)

Schmidt S, Nakchbandi I, Ruppert R, Kawelke N, Hess MW, Pfaller K, Jurdic P, Fassler R \& Moser M 2011 Kindlin-3-mediated signaling from multiple integrin classes is required for osteoclast-mediated bone resorption. Journal of Cell Biology 192 883-897. (doi:10.1083/jcb. 201007141)

Scott EW, Simon MC, Anastasi J \& Singh H 1994 Requirement of transcription factor PU.1 in the development of multiple hematopoietic lineages. Science 265 1573-1577. (doi:10.1126/science.8079170)
Sharma SM, Bronisz A, Hu R, Patel K, Mansky KC, Sif S \& Ostrowski MC 2007 MITF and PU.1 recruit p38 MAPK and NFATc1 to target genes during osteoclast differentiation. Journal of Biological Chemistry 282 15921-15929. (doi:10.1074/jbc.M609723200)

Sharma SM, Sif S, Ostrowski MC \& Sankar U 2009 Defective co-activator recruitment in osteoclasts from microphthalmia-oak ridge mutant mice. Journal of Cellular Physiology 220 230-237. (doi:10.1002/jcp.21755)

Simonet WS, Lacey DL, Dunstan CR, Kelley M, Chang MS, Luthy R, Nguyen HQ, Wooden S, Bennett L, Boone Tet al. 1997 Osteoprotegerin: a novel secreted protein involved in the regulation of bone density. Cell $\mathbf{8 9}$ 309-319. (doi:10.1016/S0092-8674(00)80209-3)

Sims NA \& Gooi JH 2008 Bone remodeling: multiple cellular interactions required for coupling of bone formation and resorption. Seminars in Cell and Developmental Biology 19 444-451. (doi:10.1016/j.semcdb.2008.07.016)

Smink JJ, Begay V, Schoenmaker T, Sterneck E, de Vries TJ \& Leutz A 2009 Transcription factor C/EBPbeta isoform ratio regulates osteoclastogenesis through MafB. EMBO Journal 28 1769-1781. (doi:10.1038/emboj.2009. 127)

Sobacchi C, Frattini A, Guerrini MM, Abinun M, Pangrazio A, Susani L, Bredius R, Mancini G, Cant A, Bishop N et al. 2007 Osteoclast-poor human osteopetrosis due to mutations in the gene encoding RANKL. Nature Genetics 39 960-962. (doi:10.1038/ng2076)

Spinardi L \& Marchisio PC 2006 Podosomes as smart regulators of cellular adhesion. European Journal of Cell Biology 85 191-194. (doi:10.1016/j.ejcb. 2005.08.005)

Sun Y, Buki KG, Ettala O, Vääraniemi JP \& Väänänen HK 2005 Possible role of direct Rac1-Rab7 interaction in ruffled border formation of osteoclasts. Journal of Biological Chemistry 280 32356-32361. (doi:10.1074/jbc. M414213200)

Ta HM, Nguyen GT, Jin HM, Choi J, Park H, Kim N, Hwang HY \& Kim KK 2010 Structure-based development of a receptor activator of nuclear factor-kappaB ligand (RANKL) inhibitor peptide and molecular basis for osteopetrosis. PNAS 107 20281-20286. (doi:10.1073/pnas.1011686107)

Takahashi N, Muto A, Arai A \& Mizoguchi T 2010 Identification of cell cycle-arrested quiescent osteoclast precursors in vivo. Advances in Experimental Medicine and Biology 658 21-30.

Takayanagi H 2009 Osteoimmunology and the effects of the immune system on bone. Nature Reviews. Rheumatology 5 667-676. (doi:10.1038/nrrheum. 2009.217)

Takayanagi H, Kim S, Koga T, Nishina H, Isshiki M, Yoshida H, Saiura A, Isobe M, Yokochi T, Inoue J et al. 2002 Induction and activation of the transcription factor NFATc1 (NFAT2) integrate RANKL signaling in terminal differentiation of osteoclasts. Developmental Cell 3 889-901. (doi:10.1016/S1534-5807(02)00369-6)

Tehrani S, Faccio R, Chandrasekar I, Ross FP \& Cooper JA 2006 Cortactin has an essential and specific role in osteoclast actin assembly. Molecular Biology of the Cell 17 2882-2895. (doi:10.1091/mbc.E06-03-0187)

Tehrani S, Tomasevic N, Weed S, Sakowicz R \& Cooper JA 2007 Src phosphorylation of cortactin enhances actin assembly. PNAS 104 11933-11938. (doi:10.1073/pnas.0701077104)

Teitelbaum S \& Zou W 2011 The osteoclast cytoskeleton: how does it work? IBMS Bonekey 8 74-83. (doi:10.1138/20110493)

Thesingh CW 1986 Formation sites and distribution of osteoclast progenitor cells during the ontogeny of the mouse. Developmental Biology 117 127-134. (doi:10.1016/0012-1606(86)90355-6)

Thesingh CW \& Scherft JP 1985 Fusion disability of embryonic osteoclast precursor cells and macrophages in the microphthalmic osteopetrotic mouse. Bone 6 43-52. (doi:10.1016/8756-3282(85)90406-5)

Tondravi MM, McKercher SR, Anderson K, Erdmann JM, Quiroz M, Maki R \& Teitelbaum SL 1997 Osteopetrosis in mice lacking haematopoietic transcription factor PU.1. Nature 386 81-84. (doi:10.1038/386081a0)

Van Wesenbeeck L, Odgren PR, Coxon FP, Frattini A, Moens P, Perdu B, MacKay CA, Van Hul E, Timmermans JP, Vanhoenacker F et al. 2007 Involvement of PLEKHM1 in osteoclastic vesicular transport and osteopetrosis in incisors absent rats and humans. Journal of Clinical Investigation 117 919-930. (doi:10.1172/JCI30328) 
Villa A, Guerrini MM, Cassani B, Pangrazio A \& Sobacchi C 2009 Infantile malignant, autosomal recessive osteopetrosis: the rich and the poor. Calcified Tissue International 84 1-12. (doi:10.1007/s00223-008-9196-4)

Wagner EF \& Eferl R 2005 Fos/AP-1 proteins in bone and the immune system. Immunological Reviews 208 126-140. (doi:10.1111/j.0105-2896. 2005.00332.x)

Wang C, Deng L, Hong M, Akkaraju GR, Inoue J \& Chen ZJ 2001 TAK1 is a ubiquitin-dependent kinase of MKK and IKK. Nature 412 346-351. (doi:10.1038/35085597)

Weaver AM, Karginov AV, Kinley AW, Weed SA, Li Y, Parsons JT \& Cooper JA 2001 Cortactin promotes and stabilizes Arp2/3-induced actin filament network formation. Current Biology 11 370-374. (doi:10.1016/S09609822(01)00098-7)

Whyte MP, Obrecht SE, Finnegan PM, Jones JL, Podgornik MN, McAlister WH \& Mumm S 2002 Osteoprotegerin deficiency and juvenile Paget's disease. New England Journal of Medicine 347 175-184. (doi:10.1056/ NEJMoa013096)

Wojtowicz A, Dziedzic-Goclawska A, Kaminski A, Stachowicz W, Wojtowicz K, Marks SC Jr \& Yamauchi M 1997 Alteration of mineral crystallinity and collagen cross-linking of bones in osteopetrotic toothless $(\mathrm{tl} / \mathrm{tl})$ rats and their improvement after treatment with colony stimulating factor-1. Bone 20 127-132. (doi:10.1016/S8756-3282(96)00336-5)

Yaroslavskiy BB, Zhang Y, Kalla SE, Garcia PV, Sharrow AC, Li Y, Zaidi M, Wu C \& Blair HC 2005 NO-dependent osteoclast motility: reliance on cGMP-dependent protein kinase I and VASP. Journal of Cell Science 118 5479-5487. (doi:10.1242/jcs.02655)

Yaroslavskiy BB, Sharrow AC, Wells A, Robinson LJ \& Blair HC 2007 Necessity of inositol $(1,4,5)$-trisphosphate receptor 1 and mu-calpain in NO-induced osteoclast motility. Journal of Cell Science 120 2884-2894. (doi:10.1242/jcs.004184)

Yoshida H, Hayashi S, Kunisada T, Ogawa M, Nishikawa S, Okamura H, Sudo T \& Shultz LD 1990 The murine mutation osteopetrosis is in the coding region of the macrophage colony stimulating factor gene. Nature 345 442-444. (doi:10.1038/345442a0)
Zaidi M, Moonga BS \& Huang CL 2004 Calcium sensing and cell signaling processes in the local regulation of osteoclastic bone resorption. Biological Reviews of the Cambridge Philosophical Society 79 79-100. (doi:10.1017/ S1464793103006262)

Zhang L, Guo YF, Liu YZ, Liu YJ, Xiong DH, Liu XG, Wang L, Yang TL, Lei SF, Guo Y et al. 2010 Pathway-based genome-wide association analysis identified the importance of regulation-of-autophagy pathway for ultradistal radius BMD. Journal of Bone and Mineral Research 25 1572-1580. (doi:10.1002/jbmr.36)

Zhao H, Laitala-Leinonen T, Parikka V \& Väänänen HK 2001 Downregulation of small gtpase rab7 impairs osteoclast polarization and bone resorption. Journal of Biological Chemistry 276 39295-39302. (doi:10.1074/ jbc.M010999200)

Zhao H, Ito Y, Chappel J, Andrews NW, Teitelbaum SL \& Ross FP 2008 Synaptotagmin VII regulates bone remodeling by modulating osteoclast and osteoblast secretion. Developmental Cell 14 914-925. (doi:10.1016/j.devcel. 2008.03.022)

Zou W \& Teitelbaum SL 2010 Integrins, growth factors, and the osteoclast cytoskeleton. Annals of the New York Academy of Sciences 1192 27-31. (doi:10.1111/j.1749-6632.2009.05245.x)

Zou W, Kitaura H, Reeve J, Long F, Tybulewicz VL, Shattil SJ, Ginsberg MH, Ross FP \& Teitelbaum SL 2007 Syk, c-Src, the alphavbeta3 integrin, and ITAM immunoreceptors, in concert, regulate osteoclastic bone resorption. Journal of Cell Biology 176 877-888. (doi:10.1083/jcb.200611083)

Zuo J, Jiang J, Chen SH, Vergara S, Gong Y, Xue J, Huang H, Kaku M \& Holliday LS 2006 Actin binding activity of subunit B of vacuolar $\mathrm{H}+$ ATPase is involved in its targeting to ruffled membranes of osteoclasts. Journal of Bone and Mineral Research 21 714-721. (doi:10.1359/jbmr.060201)

Received in final form 6 September 2011

Accepted 8 September 2011

Made available online as an Accepted Preprint 8 September 2011 